\title{
Prediksi Harga Saham Dengan Menggunakan Jaringan Syaraf Tiruan
}

\author{
Arie Bayu Untoro $\left.{ }^{*}\right)$ \\ ${ }^{1)}$ Universitas Mohammad Husni Thamrin \\ ${ }^{*}$ Correspondence Author: ariebayu.untoro@ gmail.com, Jakarta, Indonesia \\ DOI: https://doi.org/10.37012/jtik.v6i2.212
}

\begin{abstract}
Abstrak
Salah satu sektor keuangan di Indonesia adalah sektor Pasar Modal yang memperjual-belikan saham-saham perusahaan publik. Dewasa ini investasi di Pasar Modal mulai digemari oleh masyarakat, namun demikian banyak masyarakat awam yang belum memahami analisis fundamental maupun teknikal untuk pengambilan keputusan pembelian atau penjualan saham. Tujuan penelitian ini memberikan alternatif analisis saham menggunakan Jaringan Syaraf Tiruan. Algoritma yang digunakan dalam penelitian ini menggunakan back propagation. Penelitian ini menunjukan bahwa menggunakan Jaringan Syaraf Tiruan mampu memprediksi harga saham dengan rata-rata tingkat error sebesar 3.38\%. Dengan demikian penggunaan Jaringan Syaraf Tiruan untuk mempediksi harga saham dapat dijadikan alternatif dalam pengambilan keputusan pembelian atau penjualan saham.
\end{abstract}

Kata Kunci: Prediksi Harga Saham, Jaringan Syaraf Tiruan, Back Propagation.

\begin{abstract}
One of financial sector in Indonesia is the Capital Market sector which trades shares of public companies. Nowadays, investment in the capital market has begun to be popular, however, many people do not understand fundamental or technical analysis for decision making in buying or selling shares. The purpose of this study provides an alternative stock prices analysis using Artificial Neural Networks. The algorithm used in this study is back propagation. This research shows that using an Artificial Neural Network is able to predict stock prices with an average error rate of 3.38\%. Thus the use of Artificial Neural Networks to predict stock prices can be used as an alternative in the decision to buy or sell shares.
\end{abstract}

Keywords: Stock Price Prediction, Artificial Neural Network, Back Propagation.

\section{PENDAHULUAN}

Pada negara berkembang seperti di Indonesia, sektor keuangan merupakan salah satu sektor penting dalam pertumbuhan ekonomi. Sektor keuangan di Indonesia secara garis besar dibagi menjadi tiga sektor yaitu perbankan, pasar modal, dan industri keuangan nonbank. Tiga sektor keuangan tersebut sangat mempunyai andil yang signifikan pada pertumbuhan ekonomi di Indonesia. Saat ini, sektor yang menjadi perhatian di Indonesia adalah sektor pasar modal karena meningkatnya ekonomi masyarakat sehingga investasi meningkat cukup signifikan.

Industri pasar modal identik dengan saham dan surat utang atau lebih dikenal dengan obligasi. Saham merupakan bukti kepemilikan akan aset perusahaan dan obligasi merupakan bukti meminjamkan uang yang diterbitkan oleh pemerintah ataupun suatu perusahaan (Harris, 2003). Cara perdagangan untuk saham dan obligasi juga sedikit berbeda. Obligasi diperdagangkan di luar pasar (over the counter/OTC) dan saham 
diperdagangkan di Bursa Efek Indonesia (PT BEI). Saham saat ini cukup digemari oleh investor retail karena cukup murah dibanding dengan obligasi.

Para investor saham pasti menginginkan keuntungan yang tinggi. Namun demikian, berinvestasi di saham selain memberikan keuntungan yang tinggi juga memberikan risiko yang tinggi juga. Hal tersebut sesuai dengan prinsip high risk high return. Oleh sebab itu, sebelum memutuskan membeli saham maka investor perlu melakukan analisis terhadap saham yang akan dibelinya. Saat ini terdapat dua pendekatan yang cukup umum digunakan untuk melakukan analisis saham yaitu analisis fundamental dan analisis teknikal (Murkute \& Sarode, 2015). Analisis fundamental lebih dititikberatkan pada kinerja perusahaan yang menerbitkan saham. Analisis teknikal lebih condong pada analisis pergerakan grafik dengan indikator-indikator tertentu. Analisis tersebut cukuplah rumit bagi orang awam karena diperlukan pengetahuan ilmu ekonomi yang cukup dalam. Oleh sebab itu, muncul alternatif-alternatif yang lebih mudah dalam bentuk aplikasi untuk melakukan analisis terhadap saham. Analisis alternatif yang cukup banyak digunakan adalah analisis untuk memprediksi harga saham yang mana digunakan investor untuk mengambil keputusan apakah melakukan penjualan saham atau melakukan pembelian saham. Metode yang paling sering digunakan untuk memprediksi naik atau turunnya harga saham adalah jaringan syaraf tiruan (JST).

\section{METODE}

Victor dan Anthony mendifinisikan JST sebagai suatu pengolahan data dalam jumlah besar yang saling terhubung dalam melakukan pemrosesan yang mana terinspirasi dari struktur syaraf pada otak manusia (Devadoss \& Ligori, 2013). Sedangkan Mayankkumar dan Sunil mendifinisikan bahwa JST merupakan suatu set hubungan yang saling terkoneksi yang mempunyai bobot satu sama lain (Patel \& Yalamalle, 2014). Hampir senada dengan definisi sebelumnya, Reza et al mendifinisikan JST sebagai suatu model matematika atau komputasi yang terinspirasi dari jaringan syaraf biologis (Aghababaeyan, Siddiqui, \& Khan, -). Berdasarkan definisi-definisi tersebut dapat disimpulkan bahwa JST merupakan suatu model komputasi yang berupa set hubungan yang memiliki bobot yang digunakan untuk melakukan pengolahan data dalam jumlah besar.

Secara umum JST terdiri dari tiga layer yang membentuknya yaitu input layer, hidden layer, dan output layer. Cara kerja ketiga layer tersebut adalah input layer merupakan masukan nilai awal yang nantinya dilewatkan ke hidden layer berupa nilai suatu bobot untuk diproses dan nantinya akan keluar melalui output layer dalam bentuk bobot pula seperti di gambarkan pada Gambar 1. Layer pada JST diisi oleh node-node disebut sebagai 
neuron. Hidden layer tidak selalu hanya terdapat satu layer namun dapat pula ditambahkan hidden layer lagi dimana penambahan tersebut meningkatkan fleksibilitas dan akurasi pemrosesan (Patel \& Yalamalle, 2014).

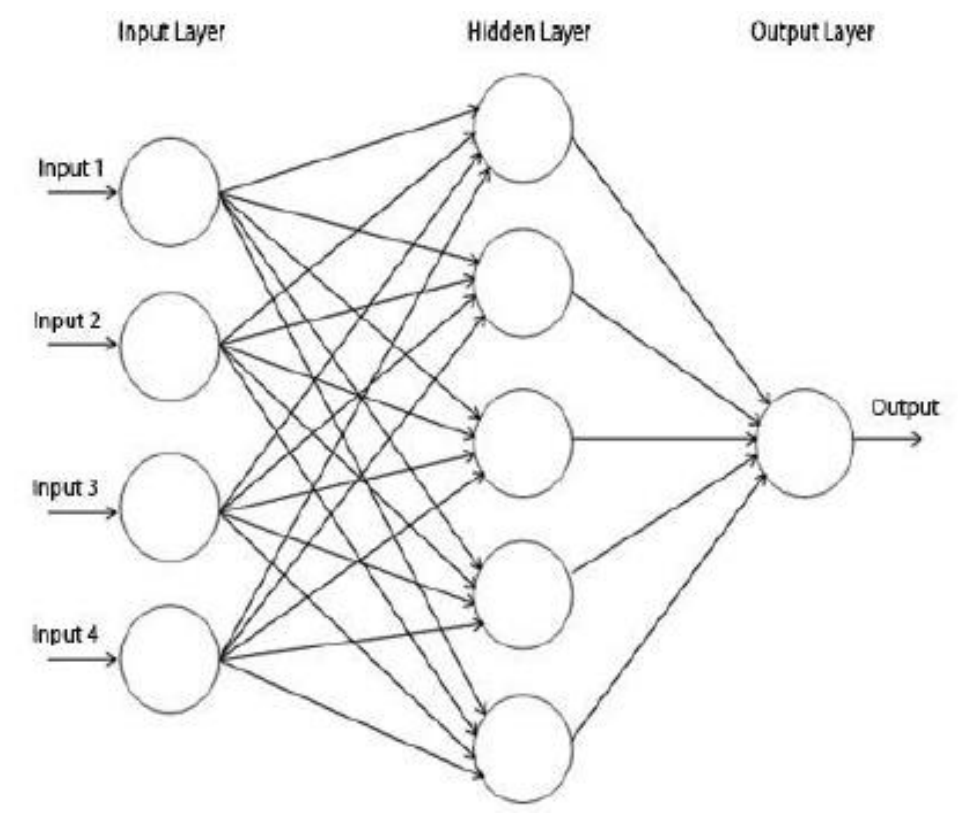

Gambar 1. Layer-layer pada jaringan syaraf tiruan (Kshirsagar, Chandel, Kakade, \& Amaria, 2016)

JST banyak digunakan dalam prediksi harga saham. Hal ini dikarenakan JST memberikan peramalan dan merupakan alat yang atraktif kepada peneliti sama baiknya dengan praktisi saham. Kelebihan JST adalah 1) memberikan kemampuan untuk mempelajari pola dari data-data yang telah ada; 2) dapat menggeneralisir dan benar dalam mengiterpretasikan data walau data tersebut banyak noise; 3) dapat disetting akurasi sampai tingkat eror yang diinginkan; dan 4) non linear (Devadoss \& Ligori, 2013).

Penelitian terkait prediksi harga saham telah banyak dilakukan. Vaibhav V. Shah et al melakukan prediksi harga saham menggunakan back propagation (Shah, Mirani, Nanavati, Narayanan, \& Pereira, 2016). Penelitian ini memberikan akurasi sebesar $98 \%$ dalam melakukan prediksi harga. Sementara itu, Mingyue Qiu et al melakukan penelitian menggunakan JST untuk memprediksi keuntungan saham di Jepang (Qiu, Song, \& Akagi, 016). Penelitian ini menggabungkan JST dengan genetic algorithm dan simulated annealing. Algoritma back propagation yang dipadukan dengan genetic algorithm dalam penelitian ini menghasilkan rata-rata error terkecil yaitu sebesar 0,009 namun waktu yang dibutuhkan cukup lama. Sedangkan gabungan algoritma back propagation dan simulated annealing menghasilkan rata-rata error sebesar 0.0862 namun memberikan waktu pemrosesan paling cepat. Amin et al juga melakukan penelitian terkait prediksi indek 
saham menggunakan JST (Moghaddam, Moghaddam, \& Esfandyari, 2016). Penelitian ini menghasilkan nilai $\mathrm{R}^{2}$ terbaik sebesar 0.9408 .

Berdasarkan penelitian-penelitian terdahulu, penelitian ini akan menggunakan JST khususnya algoritma back propagation untuk melakukan prediksi saham. Algoritma ini terbukti memberikan hasil yang cukup akurat dalam memprediksi saham. Penelitian ini tidak akan memprediksi harga saham secara langsung, namun akan memprediksi harga saham naik, tetap, ataupun turun. Saham yang akan diuji adalah saham Bank BCA (BBCA) yang telah melantai dibursa dan selalu masuk dalam daftar indek LQ45. Indek LQ45 merupakan kumpulan 45 saham yang dinilai paling liquid dan mempunyai kapitalisasi besar. Dalam pengertian lain, indek LQ45 berisi saham-saham yang paling diminati oleh investor. BBCA dipilih juga karena merupakan saham paling favorit dikalangan investor (CNBC Indonesia, 2020). Data yang dipakai adalah data saham harian dari 6 Juni 2004 sampai dengan 30 Desember 2019 sebagai data training. Data yang digunakan dalam penelitian ini diambil dari yahoo finance.

Dalam penelitian ini akan digunakan input layer sebanyak 5 neuron. Nouron-neuron tersebut akan mewakili harga saham 5 hari sebelum harga yang akan diprediksi. Hal ini disebabkan pola 5 harian tersebut sering digunakan sebagai cara analisis oleh para analis saham. Jumlah hidden layer berjumlah 11 yang didapat dua kali input layer ditambah satu node bias (Steinhauer, -). Susunan layer-layer pada penelitian ini ditunjukan pada Gambar 2.

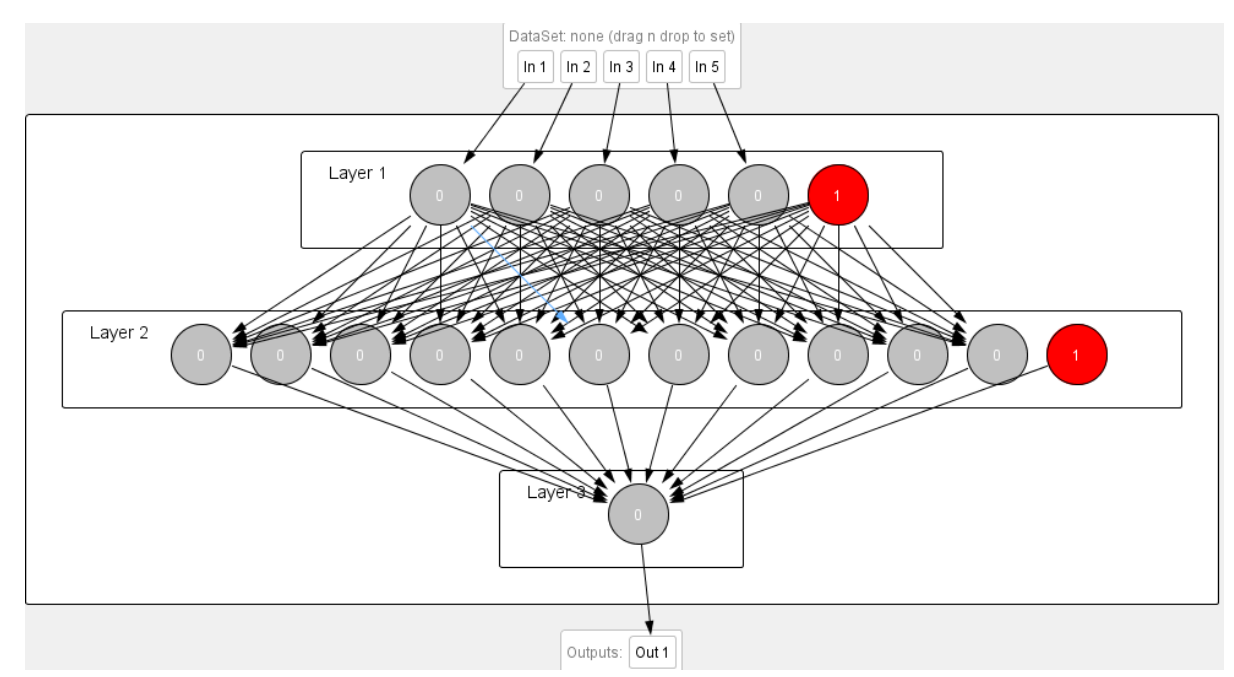

Gambar 2. Arsitektur JST yang digunakan pada penelitian ini

Penelitian ini menggunakan data harga saham BBCA yang bernilai selain null. Pada data saham BBCA yang diambil dari yahoo finance terdapat beberapa data null sehingga dengan menghilangkan data yang mengandung nilai null didapat 3.862 set data. Data tersebut akan digunakan untuk training data. Dalam penelitian ini tidak akan berhenti pada 
nilai mean square error (MSE) saja, namun akan mencoba menguji dengan harga saham real pada tanggal harga saham 1 Januari 2020 sampai dengan 31 Januari 2020. Alur penelitian dapat dilihat pada Gambar 3.

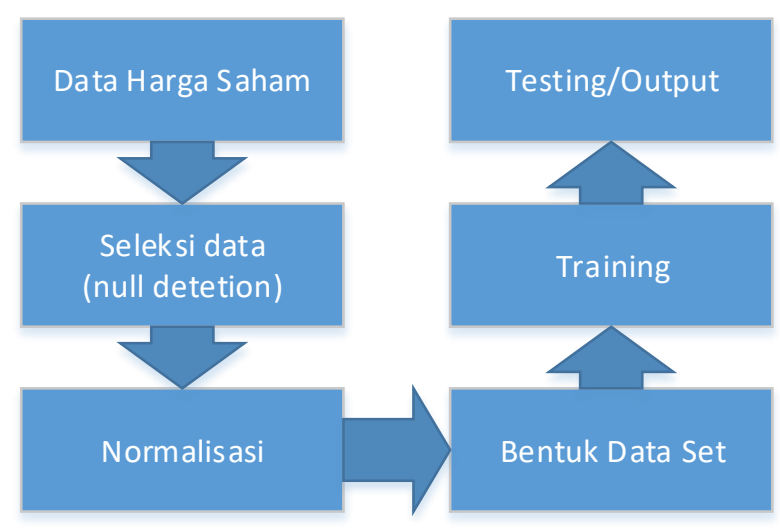

Gambar 3. Alur Penelitian.

Sebelum dilakukan training data, data terlebih dahulu dilakukan normalisasi. Normalisasi data dilakukan dengan metode nilai tertinggi dan terendah untuk dibentuk range nilai 0-1 (Nayak, Misra, \& Behera, 2014). Untuk mendapatkan nilai normalisasi (N) dilakukan sesuai dengan persamaan berikut (Murkute \& Sarode, 2015):

$$
N=(\text { Harga }- \text { Harga Terendah }) /(\text { Harga Tertinggi }- \text { Harga Terendah })
$$

Setelah seluruh data telah dinormaisasi maka data siap digunakan sebagai data input untuk training sesuai dengan JST yang dibentuk sesuai dengan Gambar 2. Output dalam pengujian akan menghasilkan nilai dengan rentang 0-1 sehingga untuk membandingkan dengan harga saham real maka dibutuhkan mekanisme denormalisasi. Denormalisasi dalam penelitian ini dilakukan untuk mendapatkan harga prediksi (D) mengunakan persamaan sebagai berikut (Murkute \& Sarode, 2015):

$$
D=\text { Output } \times(\text { Harga Tertinggi }- \text { Harga Terendah })+\text { Harga Terendah }
$$

\section{HASIL DAN PEMBAHASAN}

Penelitian ini menggunakan tool neuroph sebagai pembentukan arsitektur JST. Menggunakan konsep JST tersebut, peneliti memprediksi harga saham dengan data learning yang dihasilkan training data yang telah dijalankan. Dengan data yang telah dinormalisasi didapat MSE sebesar 0,00002 dengan jumlah iterasi 1000 kali sesuai ditunjukan Gambar 4. Nilai tersebut cukup menjanjikan karena menunjukan nilai error yang relatif kecil. Selanjutnya, dilakukan pengujian dengan menggunakan data testing yang berjumlah 22 set data. Output pengujian masih dalam rentang 0-1 sehingga perlu di 
denormalisasi menjadi nilai harga saham. Hasil output yang sudah dilakukan denormalisasi dapat dilihat pada Tabel 1.

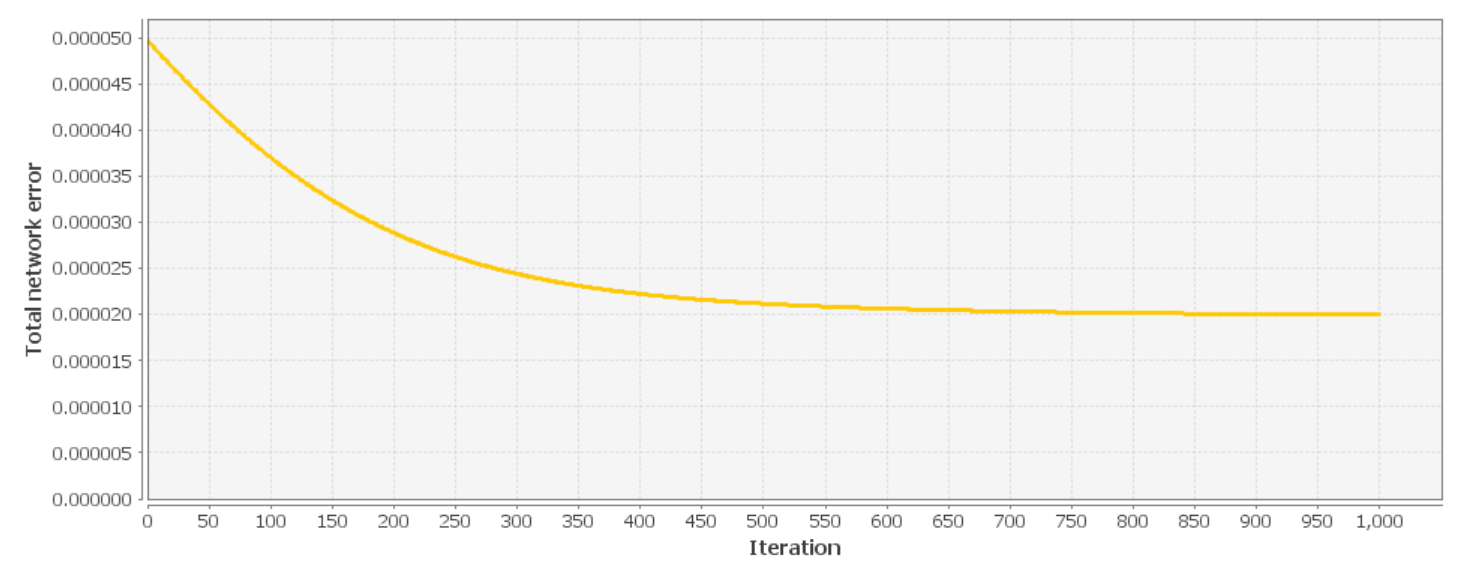

Gambar 4. Nilai Error Dalam Training Data

Tabel 1. Nilai Output setelah Denormalisasi.

\begin{tabular}{|l|l|l|}
\hline Tanggal & Output & $\begin{array}{l}\text { Nilai } \\
\text { Denormalisasi }\end{array}$ \\
\hline 02-Jan-2020 & 0.945823222 & 31983.09611 \\
03-Jan-2020 & 0.950013548 & 32122.85186 \\
06-Jan-2020 & 0.948478706 & 32071.66179 \\
07-Jan-2020 & 0.948638849 & 32077.00288 \\
08-Jan-2020 & 0.946556561 & 32007.55444 \\
09-Jan-2020 & 0.949501425 & 32105.77152 \\
10-Jan-2020 & 0.948340586 & 32067.05523 \\
13-Jan-2020 & 0.949119552 & 32093.03529 \\
14-Jan-2020 & 0.952879752 & 32218.44548 \\
15-Jan-2020 & 0.953013476 & 32222.90547 \\
16-Jan-2020 & 0.953655221 & 32244.30892 \\
17-Jan-2020 & 0.954850961 & 32284.18926 \\
20-Jan-2020 & 0.954945094 & 32287.32879 \\
21-Jan-2020 & 0.954364901 & 32267.97819 \\
22-Jan-2020 & 0.954715239 & 32279.66264 \\
23-Jan-2020 & 0.954913478 & 32286.27431 \\
24-Jan-2020 & 0.953589392 & 32242.1134 \\
27-Jan-2020 & 0.954368329 & 32268.09252 \\
28-Jan-2020 & 0.952908439 & 32219.40227 \\
29-Jan-2020 & 0.952542779 & 32207.20676 \\
30-Jan-2020 & 0.950574979 & 32141.57668 \\
31-Jan-2020 & 0.940859328 & 31817.54032 \\
\hline
\end{tabular}


Perbandingan antara harga saham dan harga saham prediksi ditunjukan pada Tabel 2. Tingkat error yang dihasilkan dari penelitian ini menghasilkan error tertinggi sebesar $4.95 \%$ dan error terkecil sebesar $0.52 \%$ sehingga didapat error rata-rata sebesar $3.38 \%$. Hal ini sejalan dengan penelitian-penelitian terdahulu yang menunjukan harga prediksi saham mempunyai rentang error yang relatif rendah walaupun menggunakan jumlah neuron pada hidden layer yang berbeda.

Tabel 2. Perbandingan harga saham dengan harga saham prediksi

\begin{tabular}{|l|l|l|l|}
\hline Tanggal & Harga & Prediksi Harga & $\%$ Error \\
\hline 02-Jan-2020 & 33422 & $31,983.10$ & 4.31 \\
03-Jan-2020 & 33102 & $32,122.85$ & 2.96 \\
06-Jan-2020 & 33127 & $32,071.66$ & 3.19 \\
07-Jan-2020 & 32832 & $32,077.00$ & 2.30 \\
08-Jan-2020 & 33127 & $32,007.55$ & 3.38 \\
09-Jan-2020 & 33053 & $32,105.77$ & 2.87 \\
10-Jan-2020 & 33151 & $32,067.06$ & 3.27 \\
13-Jan-2020 & 33766 & $32,093.04$ & 4.95 \\
14-Jan-2020 & 33594 & $32,218.45$ & 4.09 \\
15-Jan-2020 & 33667 & $32,222.91$ & 4.29 \\
16-Jan-2020 & 33790 & $32,244.31$ & 4.57 \\
17-Jan-2020 & 33594 & $32,284.19$ & 3.90 \\
20-Jan-2020 & 33569 & $32,287.33$ & 3.82 \\
21-Jan-2020 & 33618 & $32,267.98$ & 4.02 \\
22-Jan-2020 & 33618 & $32,279.66$ & 3.98 \\
23-Jan-2020 & 33471 & $32,286.27$ & 3.54 \\
24-Jan-2020 & 33618 & $32,242.11$ & 4.09 \\
27-Jan-2020 & 33373 & $32,268.09$ & 3.31 \\
28-Jan-2020 & 33348 & $32,219.40$ & 3.38 \\
29-Jan-2020 & 33127 & $32,207.21$ & 2.78 \\
30-Jan-2020 & 31849 & $32,141.58$ & 0.92 \\
31-Jan-2020 & 31652 & $31,817.54$ & 0.52 \\
\hline
\end{tabular}




\section{KESIMPULAN DAN REKOMENDASI}

Penelitian ini menguatkan penelitian-penelitian sebelumnya yang menyatakan bahwa JST merupakan salah satu cara memprediksi harga saham dengan tingkat error relatif rendah. JST dapat digunakan sebagai alat alternatif untuk memprediksi harga saham melengkapi analisis fundamental ataupun teknikal. Pendekatan prediksi harga saham menggunakan JST dapat memberikan gambaran harga saham ke depan sehingga dapat digunakan acuan investor untuk membeli saham, tahan, ataupun menjual sahamnya untuk mendapat keuntungan yang maksimal. Penelitian ini hanya memprediksi nilai harga saham dengan acuan dasar nilai 5 hari sebelum harga prediksi, namun belum menguji prediksi naik atau turun saham tersebut. Kedepan, penelitian ini dapat dilengkapi dengan melakukan prediksi apakah harga saham akan naik atau turun karena mempunyai sensitifitas data yang cukup tinggi.

\section{REFERENSI}

Aghababaeyan, R., Siddiqui, T., \& Khan, N. A. (-). Forecasting the Tehran Stock Market by Artificial Neural Network. (IJACSA) International Journal of Advanced Computer Science and Applications, -(Special Issue on Artificial Intelligence), 13-17.

CNBC Indonesia. (2020, January 2). CNBC Indonesia. (A Transmedia Company) Retrieved May 3, 2020, from https://www.cnbcindonesia.com/market/20200101134648-17126907/simak-7-saham-paling-banyak-diborong-asing-2019

Devadoss, A. V., \& Ligori, T. A. (2013). Stock Prediction Using Artificial Neural Networks. International Journal of Data Mining Techniques and Applications, 02, 283-291.

Harris, L. (2003). Trading and Exchange: Market Microstructure for Practitioners. New York: Oxford University Press.

Kshirsagar, G., Chandel, M., Kakade, S., \& Amaria, R. (2016). Stock Market Prediction using Artificial Neural Networks. International Journal of Advanced Research in Computer Engineering \& Technology (IJARCET), 5(5), 1691-1695.

Moghaddam, A. H., Moghaddam, M. H., \& Esfandyari, M. (2016). Stock market index prediction using artificial neural network. Journal of Economics, Finance and Administrative Science, 21(-), 89-93. 
Murkute, A., \& Sarode, T. (2015). Forecasting Market Price of Stock using Artificial Neural Network. International Journal of Computer Applications, 124(12), 11-15.

Nayak, S. C., Misra, B. B., \& Behera, H. S. (2014). Impact of Data Normalization on Stock Index Forecasting. International Journal of Computer Information Systems and Industrial Management Applications, 6(-), 257 - 269.

Patel, M. B., \& Yalamalle, S. R. (2014). Stock Price Prediction Using Artificial Neural Network. International Journal of Innovative Research in Science, Engineering and Technology, 3(6), 13755-13762.

Qiu, M., Song, Y., \& Akagi, F. (016). Application of artificial neural network for the prediction of stock market returns: The case of the Japanese stock market. Chaos, Solitons and Fractals, 85(-), 1-7.

Shah, V. V., Mirani, S. J., Nanavati, Y. V., Narayanan, V., \& Pereira, S. I. (2016). Stock Market Prediction using Neural Networks. International Journal of Soft Computing and Engineering (IJSCE), 6(1), 86-89.

Steinhauer, V. (-, - -). http://neuroph.sourceforge.net/. (Neuroph) Retrieved May 7, 2020, from

http://neuroph.sourceforge.net/tutorials/StockMarketPredictionTutorial.html 